\title{
Influence of Social Media Exposure on Mental Health in Relation with Covid-19 Pandemic in the State of Tamil Nadu, India
}

\author{
Gopi Rajendhiran'1, Vikhram Ramasubramanian², Anusa Mohandoss Arunachalam³, \\ Parthiban Bijulakshmi ${ }^{4}$, Raja Soundara Pandian P. ${ }^{5}$ \\ 1, 2,4,5 Department of Psychiatry, Ahana Hospitals LLP, Gandhi Nagar, Madurai, Tamil Nadu, India. \\ ${ }^{3}$ Department of Psychiatry, Shri Satya Sai Medical College and Research Institute, (Affiliated to Sri Balaji \\ Vidyapeeth), Ammapettai, Kanchipuram, Tamil Nadu, India.
}

\section{ABSTRACT}

\section{BACKGROUND}

Social media has now become the main information sharing platform, even though its reliability is questionable. Undoubtedly most of the news related to this Covid-19 pandemic has been widely spread through social media. This study aims to assess the prevalence of mental health problems in relation to social media exposure.

\section{METHODS}

A cross-sectional study was conducted via online survey through Google forms, from May $15^{\text {th }}$ to May 25 2020 among people aged 18 years and above in Tamil Nadu, India. Depression, Anxiety and Stress were measured by using DASS-21 (Depression, Anxiety and Stress Scale) and general health state was measured by GHQ 12 (General Health Questionnaire) along with sociodemographic details \& social media exposure. Descriptive statistics were performed on sociodemographic data \& Chi square analysis was performed to evaluate the magnitude of the association between social media exposure and psychological distress.

\section{RESULTS}

In a total of 1200 respondents, $35.5 \%$ of people (427) were reported as often \& most often exposed to social media and $37.9 \%$ of people were reported as 'sometimes' exposed to social media. DASS 21 domains revealed that there was some form (mild to severe) of depression in $34 \%$ of respondents, $37.1 \%$ having anxiety and $19.3 \%$ experienced stress, and its association with social media exposure was statistically significant.

\section{CONCLUSIONS}

Social media exposure does have a high impact in people's perception about Covid19 which has been significantly affecting public mental health. Controlling the spread \& monitoring the reliability of the information in social media about Covid 19 would be a great help in managing the public mental health.

\section{KEY WORDS}

Covid-19, Social Media, Exposure-Mental Health Issues
Corresponding Author: Mr. Gopi Rajendhiran. Plot No 6, 5th cross st, TM Nagar, Madurai- 625007, Tamil Nadu, India E-mail: gopirajendhiran@gmail.com

DOI: $10.14260 /$ jemds/2020/739

How to Cite This Article: Rajendhiran G, Ramasubramanian $V$, Arunachalam AM, et al. Influence of social media exposure on mental health in relation with covid-19 pandemic in the state of tamil nadu, india. J Evolution Med Dent Sci 2020;9(45):3362-3366, DOI: $10.14260 / \mathrm{jemds} / 2020 / 739$

Submission 02-07-2020,

Peer Review 30-09-2020,

Acceptance 06-10-2020,

Published 09-11-2020.

Copyright (C) 2020 Gopi Rajendhiran et al. This is an open access article distributed under Creative Commons Attribution License [Attribution 4.0 International (CC BY 4.0)] 


\section{BACKGROUND}

WHO$^{1}$ (World Health Organization) declared Covid 19 as a pandemic on 11 March 2020 and issued certain guidelines on how to handle the global crisis. The virus spreads through small respiratory droplets when an infected person coughs sneezes and speaks, and by aerosols that tend to remain in the air and surfaces for longer time. When people come into contact with these contaminated surfaces ${ }^{2}$ they also get infected. Covid-19 transmissibility, has been estimated at 4.08, suggesting that on an average, every Covid-19 infected person will spread the infection to 4 new persons. ${ }^{1}$ As of $3^{\text {rd }}$ August 2020, the WHO reported 1,79,18, 582 cases and 6,86,703 deaths worldwide ${ }^{2}$ and 5,86,244 confirmed cases in India, with 39,795 total deaths as of August $5^{\text {th }}$ as released by the Indian Ministry Of Health And Family Welfare. Maharashtra \& Tamilnadu in India, being in the top 2.3 This global outbreak has created panic among people and triggered mental health problems. Based on previous findings it had been found that, the Covid-19 pandemic has caused a severe psychological impact on people, affecting their personal and social life. As an individual, during a pandemic, a person is likely to experience anxiety of falling sick and dying, feelings of helplessness, and other stigma associated with the illness. ${ }^{4}$ Psychological reactions of people during any public health emergency play a key role in controlling the outbreak and dealing with emotional distress and the prevalence of mental health problems increases during such outbreaks which was also evident during this Covid-19 pandemic. ${ }^{5}$ The official departments and various NGO's have stepped in to help in this crisis by providing awareness, essential commodities. Many Health organizations have started tele-consultation and are providing counselling services. ${ }^{6}$ Though Indian central \& state Governments and national \& regional medias have been regularly providing awareness and updating the prevalence about Covid 19, people using several social media platforms such as Facebook, WhatsApp, YouTube, have been circulating information that are sometimes incorrect and misleading. This has been infusing stigma about the illness and causing panic among people. ${ }^{7}$

The aim of the study is to understand the three major mental health conditions such as depression, anxiety \& stress among people in India and their association with social media exposure.

\section{METHODS}

\section{Design and Participants}

This cross-sectional study was conducted online from May $15^{\text {th }}$, 2020 to May $25^{\text {th }} 2020$, which is the $4^{\text {th }}$ phase of lockdown when the infection rate was increasing alarmingly. The study approval was obtained from the Institute Ethics committee (Radianz Healthcare \& Research, Madurai, Tamil Nadu State, India) and informed consent obtained from people with given assurance of no personal identification details will be revealed such as personal phone number or mail ID obtained. People above 18 years and people from various districts of Tamil Nadu in India were included in this study. The study consisted of basic sociodemographic details, statements regarding usage of social media to get information about Covid 19 and questions in the Depression, Anxiety and Stress Scale and GHQ-12.
An online survey through Google survey platform in English \& local language Tamil (with back translation verified (https://forms.gle/NoEs17ArwJcU5EYD7) was created to assess the mental health problems among people during Covid19 and shared in public platforms. In total, 1,232 participants took part in the survey. 32 incomplete samples were excluded and 1200 participants from various districts of Tamil Nadu were involved in this study.

\section{Measurements}

Based on previous studies, 3 major mental disorders such as depression, anxiety \& stress were assessed in the current study. GHQ-12 is a measure of current mental health and was developed by Goldberg in $1970 .{ }^{8}$ Each item is rated on a 4-point scale (less than usual-no more than usual-rather more than usual-more than usual). It gives a total score of 36 and the most common scoring method is bi-modal (0-0-1-1) and Likert scoring style (0-1-2-3).

A self-reporting scale called Depression, Anxiety and Stress Scale consisting of 21 Items (DASS-21-short version) was used. It is a 4-point Likert scale developed by Lovibond, S.H. \& Lovibond, P.F. (1995) ${ }^{9}$ used to assess the levels of depression, anxiety \& stress. DASS-21 contains 7 items for each disorder and the summed scoring indicates the severity of each disorder ranging from normal, mild, moderate, severe \&extremely severe. Scores of the DASS 21 has to be multiplied with 2 and then summed. The total score of the items of each disorder indicates its severity level.

A questionnaire was prepared to evaluate the social media exposure about Covid-19 "how involved are you when you receive information about Covid-19 on social media platform" and scored with 3 point Likert scale " Never, Less, Sometimes, Often, Very Often".10

\section{Covariates}

The following covariates were included in this study: gender, age (18 - 25, 26 - 30, 31 - 40, 41 - 50, 51 - 60, 61 \& above), educational level (till school, diploma, graduation, postgraduation, $\mathrm{PhD}$, miscellaneous) marital status (married, unmarried, separated, widowed, divorcee) and occupation (student, private employee, government employee, selfemployed, unemployed).

\section{Method of Data Collection}

An online survey through Google survey platform in English \& local language Tamil (with back translation verified (https://forms.gle/NoEs17ArwJcU5EYD7) was created. The survey contained statements pertaining to personal information, socio-demographic details and place of residence. It had closed ended questions regarding their use of social media in relation to receiving information about Covid 19. It had also statements in DASS-21 and GHQ-12. The survey link was shared through WhatsApp, Instagram pages and through status updates from May $15^{\text {th }}, 2020$ to May 25th 2020, with an open invitation to participate in the survey explaining that the survey was to study the influence of social media in processing information regarding Covid 19. Participants were assured that no personal information would be collected and that individual responses would be held confidential. 


\section{Statistical Analysis}

Received data was statistically analysed using Statistical Package for Social Services software, (IBM Corp. Released 2016. IBM SPSS Statistics for Windows, Version 24.0. Armonk, NY: IBM Corp). Descriptive statistics was performed to evaluatethe prevalence of psychological distress as assessed in GHQ and levels of depression, anxiety \& stress as assessed in DASS. Mean \pm standard deviation (SD), median for covariates. 2 tailed Pearson correlation with 0.01 significance level was performed to analyse the inter correlation of sub-domains of GHQ \& DASS. Association between social media exposure \& psychological distress, depression, anxiety \& stress were analysed using Chi square test and presented as Relative Risk Ratios (RRR) with 95 $\%$ CI (Confidence Interval). Goodness-of fit-test ${ }^{11}$ was used to assess the model fit. $\mathrm{P}<0.05$ was considered statistically significant.

\section{RESULTS}

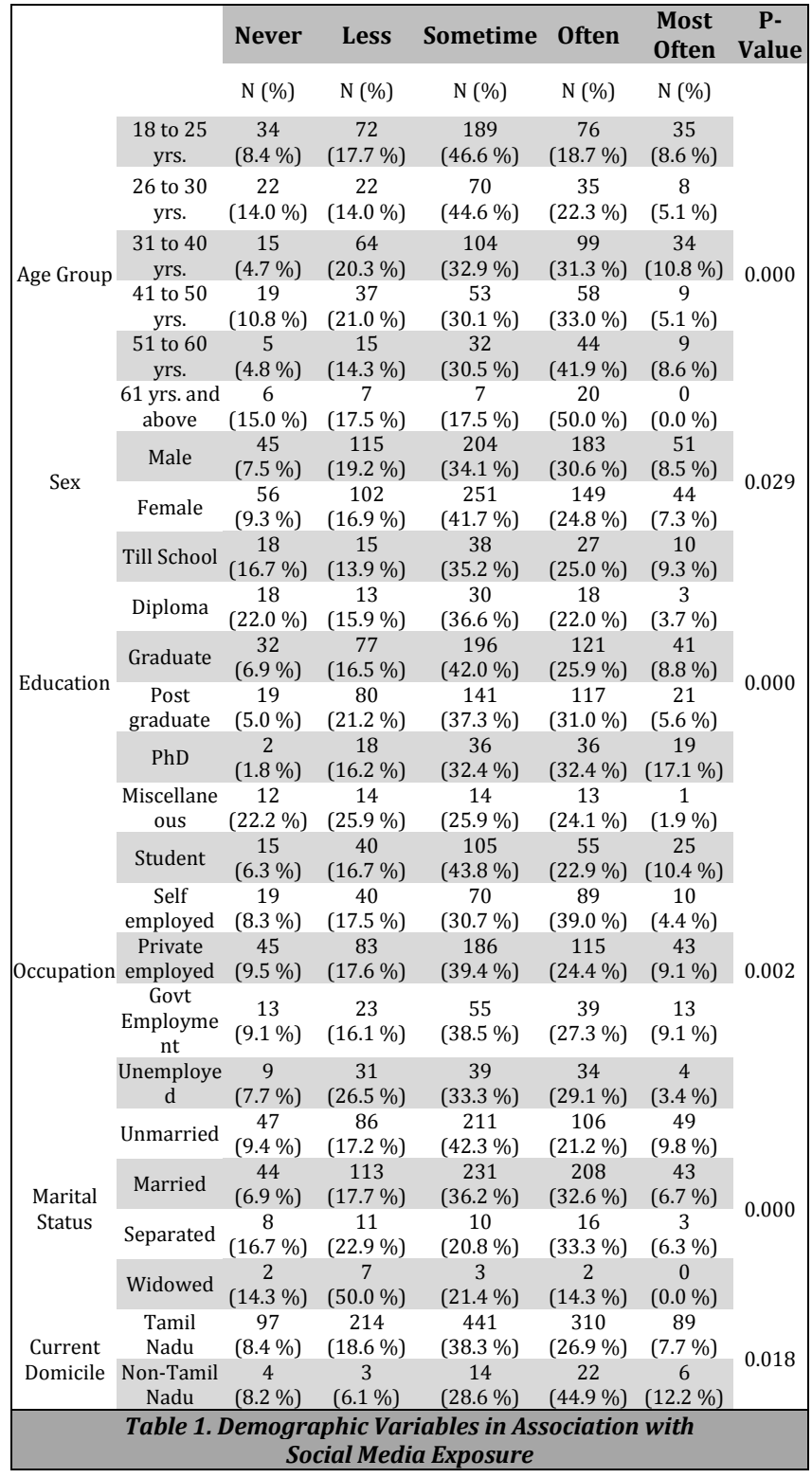

In total of 1200 respondents received from various districts of Tamil Nadu, India, there were almost equal distribution between 598 males (49.8\%) \& 602 females (50.2\%) and most of them were aged 18 to 25 (402-33.8\%). 845 (70.4\%) people were graduates or postgraduates and $111(9.2 \%)$ were $\mathrm{PhD}$ holders. 639 (53.2\%) people were married. 843 (70.3\%) people were employed either self or private or government sector and 49 (4\%) people though native to the state of Tamil Nadu lived in other states. As shown in Table 1, the distribution of the study population in terms of age group, sex, education, occupation, marital status and domicile was not uniform between social media exposure. With relation to social media exposure, $35.5 \%$ of people (427) reported as 'often \& most often and $37.9 \%$ of people reported as 'sometime'.

Based on the descriptive statistical analysis Mean \pm SD [minimum-maximum], the results of GHQ 12 in association with social media exposure with respect to the domains such as depression \& anxiety, social dysfunction, loss of confidence was $4 \pm 3.10[0-12], 6.92 \pm 3.6[0-18]$ and $1.27 \pm 1.55[0-6]$ respectively. The mean overall score for GHQ 12 psychological distress was $12.19 \pm 7.28$ [0 - 36]. There is a difference in scores of GHQ 12 domains with statistical significance (Table 2). There was not much difference in the mean scores of the domains of GHQ 12 in relation to amount of exposure to social media. But there is a significant difference in the mean score of people who were never using social media in relation to people using social media as a platform to obtain information about Covid-19. This indicated that social media exposure in context of the Covid-19 pandemic, had a significant influence in measures of GHQ 12.

\begin{tabular}{|c|c|c|c|c|c|c|c|}
\hline & & $\mathbf{N}$ & Mean & $\begin{array}{c}\text { Std. } \\
\text { Deviation }\end{array}$ & \begin{tabular}{|r}
95 \\
Confi \\
Inter \\
Me \\
Lower \\
Bound
\end{tabular} & $\begin{array}{l}\% \\
\text { dence } \\
\text { val for } \\
\text { ean } \\
\text { Upper } \\
\text { Bound }\end{array}$ & $\begin{array}{c}\text { Kruskal } \\
\text { Wallis } \\
\text { Test } \\
\text { P-Value }\end{array}$ \\
\hline \multirow{8}{*}{$\begin{array}{c}\text { GHQ12 } \\
\text { Depression \& } \\
\text { Anxiety }\end{array}$} & Never & 101 & 1.3465 & 1.97198 & .9572 & 1.7358 & \multirow{6}{*}{0.000} \\
\hline & Less & 217 & 3.5253 & 3.10474 & 3.1099 & 3.9408 & \\
\hline & Sometime & 455 & 3.9802 & 2.94846 & 3.7086 & 4.2519 & \\
\hline & Often & 332 & 4.9639 & 3.03831 & 4.6358 & 5.2919 & \\
\hline & Most often & 95 & 4.6000 & 3.20372 & 3.9474 & 5.2526 & \\
\hline & Total & 1200 & 3.9975 & 3.10250 & 3.8218 & 4.1732 & \\
\hline & Never & 101 & 3.6436 & 3.41053 & 2.9703 & 4.3168 & \\
\hline & Less & 217 & 6.6267 & 3.54649 & 6.1522 & 7.1013 & \\
\hline GHQ12 social & Sometime & 455 & 7.0923 & 3.35168 & 6.7835 & 7.4011 & \\
\hline dysfunction & Often & 332 & 7.6807 & 3.35068 & 7.3190 & 8.0425 & 0.000 \\
\hline & Most often & 95 & 7.6105 & 3.98213 & 6.7993 & 8.4217 & \\
\hline & Total & 1200 & 6.9217 & 3.60018 & 6.7178 & 7.1256 & \\
\hline & Never & 101 & .4851 & .95513 & .2966 & .6737 & \\
\hline & Less & 217 & 1.1014 & 1.25420 & .9336 & 1.2692 & \\
\hline GHQ12 Loss & Sometime & 455 & 1.3538 & 1.59848 & 1.2066 & 1.5011 & \\
\hline of confidence & Often & 332 & 1.4970 & 1.70214 & 1.3132 & 1.6808 & 0.000 \\
\hline & Most often & 95 & 1.3263 & 1.65312 & .9896 & 1.6631 & \\
\hline & Total & 1200 & 1.2725 & 1.55411 & 1.1845 & 1.3605 & \\
\hline & Never & 101 & 5.4752 & 5.45269 & 4.3988 & 6.5517 & \\
\hline & Less & 217 & 11.2535 & 7.04584 & 10.3107 & 12.1962 & \\
\hline GHQ12 & Sometime & 455 & 12.4264 & 6.89079 & 11.7915 & 13.0612 & \\
\hline dicctroc & Often & 332 & 14.1416 & 7.09418 & 13.3757 & 14.9075 & 0.000 \\
\hline & Most often & 95 & 13.5368 & 7.56927 & 11.9949 & 15.0788 & \\
\hline & Total & 1200 & 12.1917 & 7.27764 & 11.7795 & 12.6038 & \\
\hline
\end{tabular}

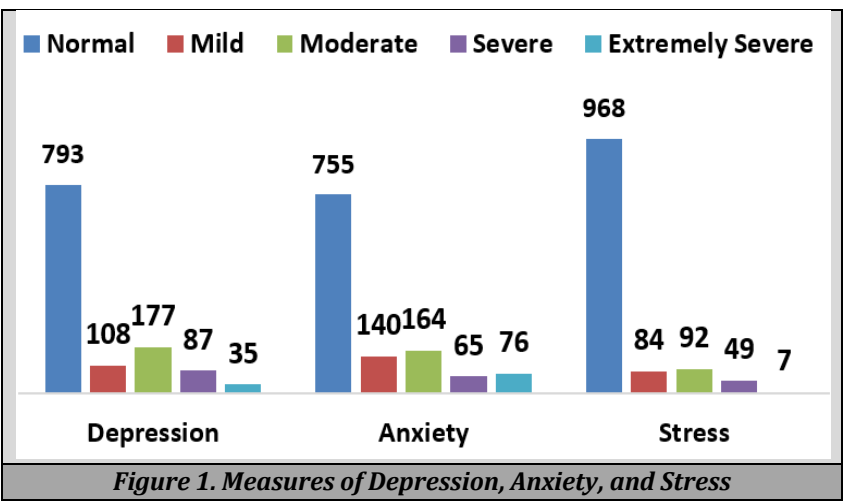




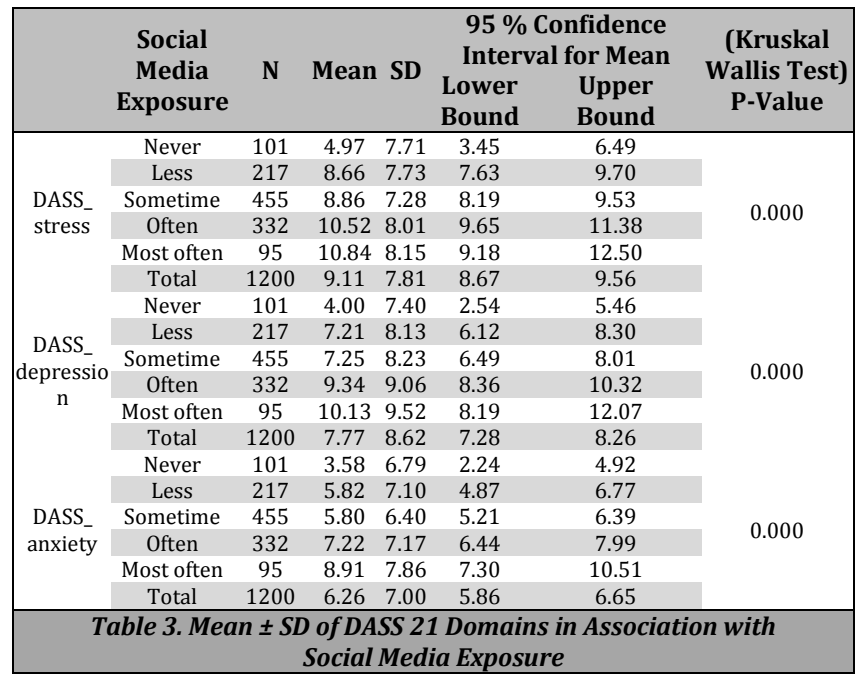

Inter correlation between GHQ-12 domains and DASS-21 domains were performed using 2 tailed Pearson correlation analysis which showed very good correlation at sig $=0.01$. Influence of social media exposure on DASS 21 domains was significant at $\mathrm{p}=0.000$ [Table 3]. The scores revealed depression in $34 \%$ of respondents, $37.1 \%$ suffered from anxiety and $19.3 \%$ were experiencing stress as shown in Figure 1.

\begin{tabular}{|c|c|c|c|c|c|c|c|c|}
\hline 苛 & & 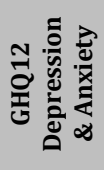 & 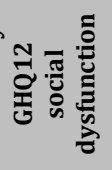 & 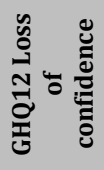 & 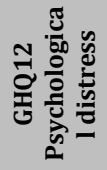 & 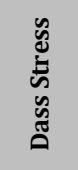 & ڤ & 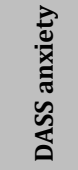 \\
\hline $\begin{array}{l}\text { GHQ12 } \\
\text { Depressi } \\
\text { on \& } \\
\text { Anxiety }\end{array}$ & $\begin{array}{l}\text { Pearson } \\
\text { Correlati } \\
\text { on }\end{array}$ & 1.00 & $.682^{* *}$ & $.655^{* *}$ & $.903^{* *}$ & $.557^{* *}$ & $.548^{* *}$ & $.468^{* *}$ \\
\hline & $\begin{array}{l}\text { Sig. (2- } \\
\text { tailed) }\end{array}$ & & 0.00 & 0.00 & 0.00 & 0.00 & 0.00 & 0.00 \\
\hline $\begin{array}{l}\text { GHQ12 } \\
\text { social } \\
\text { dysfuncti } \\
\text { on }\end{array}$ & $\begin{array}{l}\text { Pearson } \\
\text { Correlati } \\
\text { on }\end{array}$ & $.682^{* *}$ & 1.00 & $.574^{* *}$ & $.908^{* *}$ & $.527^{* *}$ & $.559 * *$ & $.465^{* *}$ \\
\hline & $\begin{array}{l}\text { Sig. (2- } \\
\text { tailed) }\end{array}$ & 0.00 & & 0.00 & 0.00 & 0.00 & 0.00 & 0.00 \\
\hline $\begin{array}{l}\text { GHQ12 } \\
\text { Loss of } \\
\text { confidenc } \\
\text { e }\end{array}$ & $\begin{array}{c}\text { Pearson } \\
\text { Correlati } \\
\text { on }\end{array}$ & $.655^{* *}$ & $.574^{* *}$ & 1.00 & $.776^{* *}$ & $.587^{* *}$ & $.660^{* *}$ & $.547^{* *}$ \\
\hline & $\begin{array}{l}\text { Sig. (2- } \\
\text { tailed) }\end{array}$ & 0.00 & 0.00 & & 0.00 & 0.00 & 0.00 & 0.00 \\
\hline $\begin{array}{l}\text { GHQ12 } \\
\text { Psycholo } \\
\text { gical } \\
\text { distress }\end{array}$ & $\begin{array}{l}\text { Pearson } \\
\text { Correlati } \\
\quad \text { on }\end{array}$ & $.903^{* *}$ & $.908^{* *}$ & $.776^{* *}$ & 1.00 & $.624^{* *}$ & $.651^{* *}$ & $.546^{* *}$ \\
\hline & $\begin{array}{l}\text { Sig. (2- } \\
\text { tailed) }\end{array}$ & 0.00 & 0.00 & 0.00 & & 0.00 & 0.00 & 0.00 \\
\hline $\begin{array}{c}\text { DASS } \\
\text { STRESS }\end{array}$ & $\begin{array}{l}\text { Pearson } \\
\text { Correlati } \\
\text { on }\end{array}$ & $.557^{* *}$ & $.527^{* *}$ & $.587^{* *}$ & $.624^{* *}$ & 1.00 & $.835^{* *}$ & $.828^{* *}$ \\
\hline & $\begin{array}{l}\text { Sig. }(2- \\
\text { tailed) }\end{array}$ & 0.00 & 0.00 & 0.00 & 0.00 & & 0.00 & 0.00 \\
\hline $\begin{array}{l}\text { DASS } \\
\text { DEPRESS } \\
\text { ION }\end{array}$ & $\begin{array}{l}\text { Pearson } \\
\text { Correlati } \\
\quad \text { on }\end{array}$ & $.548^{* *}$ & $.559 * *$ & $.660^{* *}$ & $.651^{* *}$ & $.835^{* *}$ & 1.00 & $.806^{* *}$ \\
\hline & $\begin{array}{l}\text { Sig. (2- } \\
\text { tailed) }\end{array}$ & 0.00 & 0.00 & 0.00 & 0.00 & 0.00 & & 0.00 \\
\hline $\begin{array}{l}\text { DASS } \\
\text { ANXIETY }\end{array}$ & $\begin{array}{l}\text { Pearson } \\
\text { Correlati } \\
\text { on }\end{array}$ & $.468^{* *}$ & $.465^{* *}$ & $.547^{* *}$ & $.546^{* *}$ & $.828^{* *}$ & $.806^{* *}$ & 1.00 \\
\hline & $\begin{array}{l}\text { Sig. (2- } \\
\text { tailed) }\end{array}$ & 0.00 & 0.00 & 0.00 & 0.00 & 0.00 & 0.00 & \\
\hline \multicolumn{9}{|c|}{$\begin{array}{l}\text { Table 4. Pearson Correlation between } \\
\text { GHQ } 12 \text { \& DASS } 21 \text { Domains } p<0.01\end{array}$} \\
\hline
\end{tabular}

\section{DISCUSSION}

According the National Mental Health Survey conducted in India in 2015 , the prevalence of any mental disorder in India is about $10.6 \%$ and the prevalence of depressive disorder and neurotic disorder is $2.7 \%$ \& $6.6 \%$ respectively. ${ }^{12}$ In comparison with the national data, this study revealed a significant increase, with 34 $\%, 37.1 \%$ and $19.3 \%$ experiencing some level of depression, anxiety \& stress respectively during this Covid-19 pandemic. The study shows that the social media exposure was high among the sample, with $35.5 \%$ of people reported as 'often \& most often and of people reported as 'sometime'.

This study sample shows that people in age group of 18 - 25 yrs. and $31-40$ yrs. we're using social media as the most used media for collecting information about Covid 19 and higher percentage of older people between age group of $50 \mathrm{yrs}$. and above reported that they never used social media or used it to a minimal range to gather information. While comparing education with relation to social media, the results show that the education has no influence on how people gathered information. The scores in the GHQ domains indicates that the use of social media has a significant influence on the general health of the sample as seen by the scores in loss of confidence, psychological distress, anxiety, depression and social dysfunction. The scores in DASS domains show that social media exposure has a high significance in influencing the level of stress, depression and anxiety among the sample. Correlation between the subdomains of DASS and GHQ scale indicates that psychological distress is highly correlated with stress, anxiety and depression.

In accordance with other studies showing social media as the main medium of assessing news, ${ }^{13}$ the current study had also shown that a high percentage of people (83\%) received information about Covid-19 through social media and that it had a significant influence in causing psychological distress.

During Covid-19 outbreak, false information and unscientific treatment plans about the Covid-19 have been spread through social media which has created panic and fear among many netizens, which caused confusion and anxiety among people which attributed to people's mental health problems. ${ }^{14}$ Besides, many people reacted by expressing their negative feelings such as fear, worry, nervousness and anxiety in social media, which is contagious. ${ }^{15}$

There have been some limitations that should be considered in this study. This study is cross-sectional, and causal relationship between social media exposure and mental health could not be definitely said and additional longitudinal studies, such as cohort studies or nested case-control studies are essential in the future to establish a strong temporal correlation between social media exposure \& mental health issues. Although the sample was in adequate size, the survey was conducted online for the convenience of doing rapid assessment. There is possibility of respondent bias and the fact that people who are educated and having knowledge about internet usage responded in this, may have affected the results. Finally, although the authors were able to control for many covariates, the possibility of residual unmeasured confounding factors cannot be excluded. 


\section{CONCLUSIONS}

Social media has become a tool for news collection and people exposed to social media were unaware of the reliability of the news, which plays a major role in creating irrational beliefs \& unscientific action towards Covid-19 pandemic management. 16 This study revealed a significant correlation between social media exposure and mental health issues. Mental health issues are going to be the ongoing problem which affects the country'sstate's, socio-economic balance ${ }^{17}$ and more attention has to be paid to it along with the battle of containing the Covid-19. Guidance for managing this mental health crisis issued by NIMHANS (National Institute of Mental Health and NeuroSciences) suggests various psychosocial measures including tele-consultation. ${ }^{18}$ Depression, anxiety \& psychological stress are the most common mental health issues which can affect the quality of life, family happiness, and socioeconomic status. It is the need of the hour to pay more attention in dealing with these major mental health disorders. ${ }^{19,20}$

Data sharing statement provided by the authors is available with the full text of this article at jemds.com.

Financial or other competing interests: None.

Disclosure forms provided by the authors are available with the full text of this article at jemds.com.

\section{REFERENCES}

[1] Cao Z, Zhang Q, Lu X, Pfeiffer D, Jia Z, Song H, et al. Estimating the effective reproduction number of the 2019nCoV in China. medRxiv 2020.

[2] WHO. Corona virus disease (COVID 19) situation report196. 2020. https://www.who.int/docs/defaultsource/coronaviruse/situation-reports/20200803-covid19-sitrep-196-cleared.pdf? sfvrsn=8a8a3ca4_6

[3] WHO - India. Novel coronalvirus disease (COVID 19) situation update report - 17. https://www.who.int/docs/defaultsource/wrindia/situation-report/india-situation-report17.pdf?sfvrsn=6627059a_2.

[4] Hall RCW, Hall RCW, Chapman MJ. The 1995 Kikwit Ebola outbreak: lessons hospitals and physicians can apply to future viral epidemics. Gen Hosp Psychiatry 2008;30(5):446-52.

[5] Pfefferbaum B, North CS. Mental Health and the Covid-19 Pandemic. N Engl J Med 2020;383:510-12.
[6] Gao J, Zheng P, Jia Y, et al. Mental health problems and social media exposure during COVID-19 outbreak. PLoS One 2020;15(4):e0231924.

[7] Roy D, Tripathy S, Kar SK, et al. Study of knowledge, attitude, anxiety \& perceived mental healthcare need in Indian population during COVID-19 pandemic. Asian J Psychiatr 2020;51:102083.

[8] Hillier G. The 12-Item General Health Questionnaire (GHQ12). Soc Psychiatry Psychiatr Epidemiol 1979;9:139-45.

[9] Antony MM, Bieling PJ, Cox BJ, et al. Psychometric properties of the 42-item and 21-item versions of the Depression Anxiety Stress Scales in clinical groups and a community sample. Psychol Assess 1998;10(2):176-81.

[10] Gao J, Zheng P, Jia Y, et al. Mental health problems and social media exposure during COVID-19 outbreak. SSRN Electron J 2020;1(1);1-26.

[11] Yockey RD, Yockey RD. The Chi-Square goodness of fit test. In: SPSS® Demystified. 2018.

[12] Murthy RS. National Mental Health Survey of India 20152016. Indian Journal of Psychiatry 2017;59(1):21-6.

[13] Bao Y, Sun Y, Meng S, et al. 2019-nCoV epidemic: address mental health care to empower society. The Lancet 2020;395(10224):e37-e8.

[14] Rovetta A, Bhagavathula AS. COVID-19-related web search behaviors and infodemic attitudes in Italy: Infodemiological study. J Med Internet Res Pub Health Surv 2020;6(2):e19374.

[15] Kramer ADI, Guillory JE, Hancock JT. Experimental evidence of massive-scale emotional contagion through social networks. Proc Natl Acad Sci U S A 2014;111(29):10779.

[16] Kadam AB, Atre SR. Social media panic and COVID-19 in India. J Travel Med 2020;27(3):taaa057.

[17] McDaid D, Knapp M, Raja S. Barriers in the mind: promoting an economic case for mental health in low- and middleincome countries. World Psychiatry 2008;7(2):79-86.

[18] Mental health in the times of covid 19 pandemic department of psychiatry, NMHANS. http://nimhans.ac.in/wpcontent/uploads/2020/04/MentalHealthIssuesCOVID19NIMHANS.pdf

[19] Doran CM, Kinchin I. A review of the economic impact of mental illness. Aust Heal Rev 2019;43(1):43-8.

[20] Evans S, Banerjee S, Leese M, et al. The impact of mental illness on quality of life: a comparison of severe mental illness, common mental disorder and healthy population samples. Qual Life Res 2007;16(1):17-29. 